\title{
Bibliografia taneCZNA. Stan literatury tanecznej w Polsce - Perspektywy badawcze
}

\author{
Alicja IwaŃsKa \\ alicjaiwanska@op.pl
}

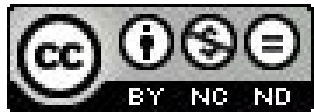

Od dłuższego czasu taniec w Polsce cieszy się rosnącą popularnością m.in. dzięki tanecznym filmom i programom telewizyjnym. Jak przysłowiowe "grzyby po deszczu" pojawiają się szkoły, warsztaty i festiwale taneczne. Wraz z tak dużym zainteresowaniem tańcem, szczególnie ludzi młodych, zauważyć można również pewne ożywienie na rynku wydawniczym. Coraz częściej na półkach księgarskich można znaleźć publikacje o tematyce tanecznej. Wzrasta liczba osób chcących poszerzyć swoją wiedzę z zakresu historii, teorii czy antropologii tańca. Mimo jednak znaczącego zainteresowania tańcem dużej grupy osób, sztuka ta, $\mathrm{w}$ tym edukacja taneczna, w Polsce traktowana jest w sposób marginalny. Wydawnictwa nie odpowiadają na rosnące zainteresowanie czytelników tą dziedziną sztuki. Większość książek o tańcu ukazuje się przypadkowo, bez śladu myśli przewodniej, często bez znajomości przedmiotu i bez rozeznania $\mathrm{w}$ potrzebach odbiorcy. Rodzi się $\mathrm{w}$ takim razie pytanie, jaki jest obecny stan literatury w Polsce w tym zakresie?

\section{Stan literatury tanecznej w Polsce}

Stan literatury tanecznej $w$ Polsce ${ }^{1}$ nie prezentuje się zbyt imponująco, jeśli by sądzić o naszym dorobku w tej dziedzinie wyłącznie na podstawie cyfr. W porównaniu z innymi krajami ilość tytułów, które ukazały się na polskim rynku wydawniczym nie prezentuje się źle. Znacznie gorzej niestety wypada jednak analiza merytoryczna.

Większość publikacji dotyczy głównie sztuki baletowej. Są to opracowania historyczne, almanachy, biografie, wspomnienia, pamiętniki, wywiady z artystami, książki z zakresu teorii, estetyki i filozofii baletu oraz metodyki tańca klasycznego. Drugą grupę stanowią książki z dziedziny tańca ludowego i historycznego, w których znajdują się opisy poszczególnych tańców z rysem historycznym i dołączonymi do nich kinetogramami. Wydano również niewielką liczbę opracowań poświęconych najważniejszym zespołom pieśni i tańca w Polsce. Kilka pozycji dotyczących technik tańca adresowanych jest do użytku amatorskiego ruchu artystycznego. Nie brakuje też książek popularyzatorskich, czy tekstów źródłowych. Literatura z dziedziny choreoterapii, choreologii, antropologii, anatomii na polskim rynku wydawniczym ukazuje się sporadycznie². Pozostałe publikacje to przede wszystkim wydawnictwa albumowe (przeważnie jubileuszowe), programy spektakli, festiwali, foldery. Ważną pozycją w literaturze tanecznej jest Bibliografia za-

1 Analizą stanu literatury tanecznej w Polsce zajmowała się m.in. Janina Pudełek. Odsyłam do dwóch jej artykułów: Powojenne ksiażki o balecie, „Pamiętnik Teatralny” 1965, z. 3-4, s. 409-416 oraz Powojenne ksiażki o balecie, „Ruch Muzyczny" 1973, nr 14, s.15-16. Z publikacji nowszych polecam teksty: Pawła Chynowskiego Dance Research and Publication zamieszczony w S. J. Cohen (ed.), International Encylopedia of Dance, New York 2004, vol. 5, s. 220-221 oraz Diagnoza stanu obecnego - Informacja [w:] J. Grabowska, J. Szymajda, Raport o tańcu wspótczesnym w Polsce w latach 1989-2009, KrakówŁódź 2009, s. 46-48.

2 Wśród niewielu pozycji z tych dziedzin należy wymienić pracę zbiorową pod red. D. Kubinowskiego, Taniec Choreologia - Humanistyka, Poznań 2000, czy też książkę z zakresu anatomii autorstwa J. G. Haas, Anatomia w tańcu, Warszawa 2011. R. Lange zajmuje się choreologią i kinetografia, a także antropologią tańca. Wyniki swoich badań zamieścił w publikacji O istocie tańca i jego przejawach w kulturze. Perspektywa antropologiczna, Kraków 1988. 
gadnień sztuki tanecznej, która ukazała się za lata 1945-1966. Niestety z przyczyn mi nieznanych zaprzestano kontynuacji tej serii, z ogromną szkodą dla środowiska tanecznego. Wciąż brakuje książek z zakresu historii i teorii tańca współczesnego, rozwoju nowatorskich form tańca w Polsce i na świecie, cielesności w tańcu czy opracowań biograficznych pionierów modern dance. Poza albumami jubileuszowymi takich zespołów, jak Polski Teatr Tańca czy Śląski Teatr Tańca (które mimo to nie są wcale dostępne w masowej dystrybucji) oraz albumem poświęconym Conradowi Drzewieckiemu (założycielowi Polskiego Teatru Tańca w Poznaniu), mamy w Polsce w tym zakresie ogromną niszę rynkową. Warto wymienić nieliczne wyjątki, np. album autorstwa Zofii Tomczyk-Watrak Teatr Ekspresji Wojciecha Misiuro, który wykracza poza zwykły rys historyczny. Na temat tańca modern ukazała się w Polsce, jak na razie jedna publikacja autorstwa Barbary Sier-Janik Post modern dance. Natomiast jedyną pozycją prezentującą panoramę współczesnego teatru tańca, z pominięciem niestety Polski, jest książka Wojciecha Klimczyka zatytułowana Wizjonerzy ciata. Wymienione pozycje wyczerpują literaturę przedmiotu w Polsce. Stanowią one istotna, aczkolwiek niepełna, dokumentację polskiego oraz światowego baletu i tańca w jego rozwoju historycznym. Obecny stan badań w Polsce nie daje możliwości odpowiedzi m.in. na pytania o treść, artystyczną jakość i znaczenie w szczególności nowatorskich poszukiwań polskich i zagranicznych artystów tańca w $X X$ w.

O złej sytuacji rynku wydawniczego pisało wiele osób ${ }^{3}$. Pozwolę sobie przytoczyć jedynie dwie. W artykule zamieszczonym w 1973 r. w „Ruchu Muzycznym” Janina Pudełek pisała: „Książki o balecie ukazują się przypadkowo, bez śladu myśli przewodniej, często bez znajomości przedmiotu, bez rozeznania w potrzebach czytelnika. (...) Brak zainteresowania wydawnictw tematyką baletową. Złożyło się na to wiele czynników, jednym z najważniejszych jest chyba jednak wzgląd na tzw. opłacalność finansową. (...) Brak redaktorów o podstawowym przygotowaniu fachowym z dziedziny baletu; brak »zaplecza « autorskiego (...); brak ośrodka, który mógłby stać się zalążkiem zorganizowanego warsztatu badań, czy choćby centrum możliwie wszechstronnych informacji z dziedziny baletu. Powstanie takiej komórki ułatwiłoby rozwiązanie czy choćby próbę przezwyciężenia wielu wyliczonych tu trudności" ${ }^{\prime \prime}$. Ponad trzydzieści lat później o równie złej sytuacji rynku wydawniczego pisze Anna Królica. W swojej refleksji autorka podkreśla, że: „rynek wydawniczy (...) nie przychodzi z pomoca; brakuje książek, periodyków, kompendiów na temat tańca współczesnego czy teatru tańca. Na półkach księgarskich znajdujemy najczęściej zapisy historii: wspomnienia, biografie, rozmowy z artystami baletu, dzieje baletu (...). Można wyodrębnić grupę stałych autorów, głównie historyków, którzy zajmowali się lub nadal opisują w sposób systematyczny wydarzenia z życia baletu, m.in. Janina Pudełek, Irena Turska, Tacjanna Wysocka, Jan Stanisław Witkiewicz, jednak nadal brakuje naukowej, teoretycznej refleksji o tańcu (nawet tym baletowym). Nieobecność tych materiałów na rynku nie tłumaczy brak naukowców czy dziennikarzy, zajmujących się tą problematyką w Polsce, bo zawsze można przekładać i wydawać książki, ukazujące się na Zachodzie, gdzie kultura tańca, także współczesnego, stoi na wysokim poziomie" ${ }^{\prime \prime}$.

Natomiast tradycja polskiego czasopisma poświęconego sztuce tanecznej nie jest długa i bogata. Taniec nie miał u nas zbyt wiele szczęścia do regularnych periodyków, których zaintere-

\footnotetext{
3 O złej sytuacji polskiego rynku książek tanecznych pisały m.in.: Janina Pudełek, Anna Królica, Joanna Szymajda, Jadwiga Grabowska (Majewska), czy Katarzyna Badura-Kozak.

J. Pudełek, Powojenne ksiażki o balecie, „,Ruch Muzyczny” 1973, nr 14, s. 15.

5 A. Królica, Taniec w sieci i na rynku wydawniczym, [w:] E. Kozak, J. Szymajda, B. Machnicka (red.), Exchange/Change. Materiały z Międzynarodowej Konferencji w ramach VII Festiwalu Ciało/Umysł, Warszawa 2009, s. 54-55.
} 
sowanie w większej mierze skupiałoby się na sprawach baletu, czy tańca w ogóle. Przed wojną w Warszawie ukazały się nakładem miesięcznika „Muzyka” dwa obszerne numery monograficzne pt. Taniec. Na czasopismo w całości poświęcone sztuce tańca trzeba było czekać aż do lat siedemdziesiątych ubiegłego wieku. Wtedy to z inicjatywy Pawła Chynowskiego powstał w Poznaniu „Taniec”, magazyn mający być z założenia kwartalnikiem, często jednak wychodzący nieregularnie. W sumie do 1986 r. ukazało się dziesięć numerów. Poznański „Taniec” starał się opisywać wszystkie najważniejsze wydarzenia z tanecznego życia Polski, a także omawiać wybrane zagadnienia zagraniczne, głównie konkursy baletowe i festiwale, w których brali udział polscy tancerze. Nie zabrakło też artykułów omawiających historię polskiego baletu, przedstawiających sylwetki wybitnych tancerzy i choreografów oraz osiąnięcia polskich artystów zagranicą. W magazynie można było znaleźć wspomnienia o tancerzach, którzy odeszli, recenzje książek o tańcu oraz wykaz audycji telewizyjnych i filmów o tańcu i tancerzach, a także prezentacji pełnospektaklowych baletów i etiud choreograficznych w polskiej telewizji. W 1986 r. trzeba było przerwać wydawanie pisma ${ }^{6}$. Dopiero po sześciu latach wznowiono „Taniec”. Tym razem wydawany był w Warszawie, a jego redaktorem pozostał P. Chynowski. Warszawski „Taniec” utrzymał główne działy poznańskiego poprzednika. Bardziej otwarta struktura pisma pozwoliła na prezentację nawet bardziej różnorodnych zjawisk z pogranicza sztuki tańca, np. pantomimy. Artykuły historyczne (Kronika Pawła Chynowskiego - 200 lat temu i Kronika Janiny Pudełek - 100 lat temu) oraz portret jednego z wybitnych artystów polskiej sceny baletowej były w każdym numerze. Także warszawski „Taniec”, mimo wysiłków redakcji, był skazany na dość nieregularny żywot, często uciekano się do wydawania numerów podwójnych, aby zachować aktualność i porządek ukazywania się. Niestety, czasopismo ostatecznie przetrwało tylko dwa lata, do 1994 r. W 2008 r. Wydawnictwo Terpsychora z Warszawy ponowiło próbę wznowienia pisma. Niestety ukazał się tylko jeden numer „Tańca” wydany na CD-ROM-ie, ze względów na niższe koszty produkcji.

Z kolei pierwszym czasopismem poświęconym tańcowi współczesnemu była „Strefa Tańca". Był to miesięcznik, który na rynku ukazał się w 2003 r. W magazynie przede wszystkim zamieszczano reportaże, wywiady, felietony. Redakcja pisma była otwarta również na niekonwencjonalne formy wypowiedzi dziennikarskiej. Pismo podzielono na dwie części. W części pierwszej przeważały teksty popularyzatorskie skierowane do szerokiego grona odbiorców. W drugiej części „Strefy Tańca” zamieszczane były teksty specjalistyczne i recenzje jednoznacznie adresowane do środowiska tanecznego, menedżerów oraz dziennikarzy. W sumie ukazało się 5 numerów. Numer 6 gotowy do druku już się nie ukazał.

„Studia Choreologica" to publikacja wydawana od 1999 r. przez Instytut Choreologii. Większość drukowanych tam tekstów, to wyniki badań naukowych z dziedziny antropologii i historii tańca. Od 2010 r. pismo jest organem Polskiego Forum Choreologicznego (PFCH). Członkowie PFCH zamieszczają w nim artykuły, które wcześniej prezentowane są podczas corocznej Konferencji Choreologicznej.

Z czasopism prezentujących taniec bardziej od strony popularyzatorskiej na rynku ukazały się dwa tytuły: „Place for Dance” (2010/2011) i „Trendy” (2008 - ). Pierwszy z tytułów niestety przestał się ukazywać po 5 numerze pisma, natomiast drugi do tej chwili miał 27 numerów ${ }^{7}$. W piśmie przeważają relacje z festiwali, konkursów, warsztatów. Czasami zamieszczane są wy-

6 Zarówno w przypadku czasopisma „Taniec”, jak i pozostałych periodyków w tym zakresie, głównym powodem zaprzestania ukazywania się danego tytułu był brak funduszy.

Do listopada $2011 \mathrm{r}$. 
wiady z osobami ze środowiska tanecznego. Część artykułów dotyczy muzyki i mody, a także zdrowia tancerzy.

Różnorodnym zagadnieniom tańca udostępniają swoje strony również takie czasopisma,

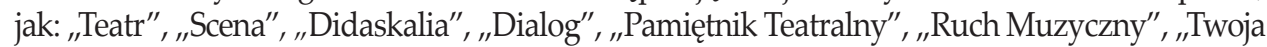
Muza”, ,"Konteksty”, czy „Opcie”. Niestety nadal brak samodzielnego pisma o tańcu. Wiele informacji o tej sztuce dociera do czytelników dzięki portalom internetowym ${ }^{8}$.

Należy mieć jedynie nadzieję, że coraz większa popularność sztuk performatywnych stanie się przesłanką dla rozwoju rynku książek o tańcu i powstania samodzielnego czasopisma o nim.

\section{Bibliografia TANECZNA}

Bibliografia to zarówno uporząqkowany według z góry ustalonych kryteriów i spełniający określone zadania informacyjne spis dokumentów pisanych, jak i dział nauki o utworach piśmiennictwa definiujący zasady tworzenia wspomnianych spisów ${ }^{9}$. W zależności od tego, co odegrało decydującą rolę $\mathrm{w}$ doborze materiału zawartego w wykazie dokumentów, można go podzielić na różne typy i rodzaje ${ }^{10}$. Przy sporządzaniu bibliografii każdy dokument należy jednoznacznie określić. Służy temu opis bibliograficzny ${ }^{11}$. W opisie wymienia się cechy formalne danej publikacji. Występują różne stopnie szczegółowości opisu w zależności od jego przeznaczenia. Opis sporządza się na podstawie dokładnej analizy dokumentu. Do analizy treści dokumentu korzystamy z tzw. pomocniczych tekstów metainformacyjnych, czyli: przedmowy, wstępu, spisu treści, indeksów, streszczenia autorskiego, charakterystyki treści umieszczonej na skrzydełku lub okładce, tytułu, podtytułu, tytułów rozdziałów, żywej paginy, przypisów lub bibliografii załącznikowej.

Bibliografie zagadnień sztuki tańca, szczególnie dotyczące publikacji angielskojęzycznych ${ }^{12}$, są na świecie opracowywane regularnie. W Polsce zestawienia literatury tanecznej nie ukazują się od prawie pół wieku. Pociąga to za sobą poważne konsekwencje. Osoby interesujące się tą dziedziną sztuki nie są w stanie stwierdzić, jakie publikacje pojawiły się na rynku wydawniczym $\mathrm{w}$ danym roku w tym zakresie.

8 A. Królica, dz. cyt., s. 57. Zob. także Gry medialne - analiza rozwoju cyfrowego rynku informacji o tańcu wospótczesnym, 2011, oprac. Sandra Wilk, Warszawa 2011.

9 Por. A. Mendykowa, Podstawy bibliografii, Warszawa 1986, s. 15.

10 Ze względu na zasięg terytorialny wyróżniamy bibliografie: międzynarodowe, narodowe, regionalne i lokalne. Ze względu na zasięg chronologiczny dzielimy je na bieżące, retrospektywne i prospektywne. Bibliografie bieżące to bibliografie ciagłe, kontynuowane, $\mathrm{w}$ których granica dolna zasięgu jest wyznaczona, górna natomiast nie jest zamknięta. Wydawane są w formie periodyków i rejestrują na bieżąco współcześnie wydawane publikacje. Najczęściej ukazują się regularnie, a ich większe całości zamykane są zbiorczymi indeksami, albo zestawiane w kumulacje. Bibliografie retrospektywne są bibliografiami zamkniętymi, rejestrują piśmiennictwo za pewien okres miniony, przy czym granica dolna i górna zasięgu chronologicznego jest ściśle wyznaczona. Wydawane są $\mathrm{w}$ formie zamkniętej publikacji, a uzupełniane lub kontynuowane mogą być drogą wznowień i suplementów. Bibliografie prospektywne stanowią zapowiedzi wydawnicze. W ramach pojęcia zakresu wyróżniamy bibliografie ogólne oraz specjalistyczne (jeśli zakres jest ograniczony do kilku lub jednego działu wiedzy, dziedziny lub zagadnienia). Spisy bibliograficzne można również podzielić ze względu na cel i przeznaczenie na: naukowe (ułatwiają orientację w piśmiennictwie dla celów badawczych) oraz pozanaukowe. Tamże, s. 20-23.

${ }_{11}$ „Opis bibliograficzny jest to zespó́ informacji niezbędnych do identyfikacji opisywanego dokumentu oraz informacji uzupełniających, które mogą być dodawane dla bliższego scharakteryzowania dokumentu". Tamże, s. 17.

12 Opracowywaniem przewodników i bibliografii publikacji dotyczących tańca, a wydawanych w języku angielskim na całym świecie, zajmuje się m.in. Leslie Getz ze Stanów Zjednoczonych. Zob. tej autorki Attitudes \& Arabesques, New York [2004] - jest to przede wszystkim przewodnik po czasopismach tanecznych oraz Dancers and choreographers. A Selected Bibliography, Rhode Island \& London, 1995 - to spis wybranych przez autorkę publikacji książkowych i artykułów dotyczących tancerzy i choreografów, których nazwiska zostały uszeregowane w kolejności alfabetycznej. 
Bibliografia zagadnień sztuki tanecznej ukazała się w Polsce za lata 1945 - 1966 i dotyczy publikacji krajowych, jak i tłumaczeń tekstów autorów obcych. Autorami tych opracowań są Irena Ostrowska i Roderyk Lange. Wydane zostały przez Sekcję Tańca Centralnej Poradni Amatorskiego Ruchu Artystycznego w Warszawie w ramach Biblioteki Metodycznej. I. Ostrowska jest autorką pięciu spisów bibliograficznych za lata 1945-1955, 1956-1957 wraz z uzupełnieniem za 19451655, 1958-1960, 1961-1962 oraz 1965-1966. Natomiast R. Lange dokonał zestawienia literatury tanecznej za okres 1963-1964. W komentarzu od redakcji Bibliografii zagadnień sztuki tanecznej z lat 1961-1962 autorka pisze: „Bibliografia zagadnień sztuki tanecznej pomyślana jest (...) jako źródło nie tylko samych danych bibliograficznych, ale jednocześnie informacji o aktualnym przebiegu rozwoju ruchu amatorskiego i zawodowego w zakresie tańca w oparciu o materiały opublikowane w wydawnictwach i prasie" ${ }^{\prime \prime 13}$. Opracowanie takiej bibliografii jest konieczne dla przedstawienia pełnego obrazu rozwoju tej dziedziny sztuki i nauki. Praca nad tego typu bibliografią zmusza do dokładnej analizy materiałów, które składają się na nią w stosunku do wydarzeń, jakie w tej dziedzinie zaistniały. Mimo ogromnej wartości informacyjnej opracowania te mają jedną poważną wadę. W każdym z nich materiał został uporządkowany/sklasyfikowany według odmiennych zasad (działów). Powoduje to pewną dezorientację. Czytelnik nim przejdzie do poszukiwania interesującej go publikacji z danego zagadnienia, musi się w pierwszej kolejności zapoznać ze spisem treści, który nie zawsze jest czytelny i zrozumiały. Niekiedy pomocne okazują się wskazówki zawarte we wstępie lub komentarzu od redakcji. Autor podaje w nim, według jakich zasad dokonał wyboru i podziału materiału oraz jakie publikacje znajdują się w poszczególnych działach.

Każda dziedzina opracowuje własny, dostosowany do potrzeb, podział dokumentów, w zależności od zakresu i ilości zebranego materiału. Jedną z najbardziej rozpowszechnionych systematyzacji publikacji, stosowanej w bibliografiach ogólnych i specjalnych, jest uniwersalna klasyfikacja dziesiętna (UKD). UKD dzieli całość wiedzy na dziesięć działów głównych ${ }^{14}$ (pierwszego stopnia) oznaczonych cyframi arabskimi od 0 do 9 . Są to:

0 Dział ogólny

1 Filozofia. Psychologia

2 Religia. Teologia

3 Nauki społeczne. Prawo. Administracja

4 (dział wolny)

5 Matematyka. Nauki przyrodnicze

6 Nauki stosowane. Medycyna. Nauki Techniczne. Rolnictwo

7 Sztuka. Rozrywki. Sport

8 Językoznawstwo. Nauka o literaturze. Literatura piękna

9 Archeologia. Prehistoria. Geografia. Biografie. Historia.

Problem z opracowaniem poszczególnych działów obejmujących różne zagadnienia dotyczące tańca wynikają z braku wyszczególnienia w dziale głównym 7 (Sztuka. Rozrywki. Sport)

13 I. Ostrowska, Bibliografia zagadnień sztuki tanecznej z lat 1961-1962, Warszawa 1964, s. 5.

${ }^{14}$ Każdy z tych działów ulega dalszemu podziałowi. UKD wykorzystuje jako alfabet, tzw. bazę notacyjna, zbiór dziesięciu cyfr od 0 do 9 . Symbol każdej klasy zawiera tyle cyfr, ile szczebli podziału poprzedza tę klasę w strukturze drzewa klasyfikacyjnego. Klasy główne są oznaczone symbolami jednocyfrowymi, klasy na drugim stopniu podziału - dwiema cyframi, na trzecim - trzema itd. Na pierwszych szczeblach podziału podaje się zagadnienia ogólne, w głąb podziałów przechodzi się do zagadnień coraz bardziej szczegółowych. Aby dokładniej sklasyfikować daną jednostkę bibliograficzną wykorzystuje się również symbole pomocnicze, które pełnią funkcje uzupełniające wobec symbolu głównego. „Układ działów i ich rozgałęzień - jeśli nawet nie odpowiada w pełni dzisiejszemu stanowi wiedzy - może być ciagle aktualizowany" . A. Mendykowa, dz. cyt., s. 30. 
Tańca, jako jednej z dziedzin sztuki. Zgodnie z obowiązującym UKD publikacje z zakresu tańca są klasyfikowane w sposób następujący:

7 Sztuka. Rozrywki. Sport

\section{Teatr}

792.8 Przedstawienia choreograficzne. Balet. Taniec sceniczny.

793 Rozrywki towarzyskie. Zabawy

793.077 Amatorskie zespoły artystyczne

Taniec (tańce narodowe, towarzyskie)

793.3.031.4 Tańce ludowe (w tym również zespoły pieśni i tańca).

Takie rozbicie literatury tanecznej nie pomaga przy poszukiwaniu danej publikacji. O ile prościej byłoby dokonać klasyfikacji publikacji z dziedziny tańca, gdyby w dziale 7 wyodrębnić Taniec, jako samodzielną klasę, tak jak Muzyka czy Teatr. Dla przykładu przedstawię, jak została sklasyfikowana literatura taneczna w bibliotece Instytutu Sztuki Polskiej Akademii Nauk w Warszawie, zgodnie z UKD:

792.75 Taniec - Polska

792.8 Balet

793.3(03) Taniec - encyklopedie i słowniki

793.3(09) Taniec - historia

Taniec - teoria

793.3(438) Estrada

793.3(47) Taniec - Rosja

W literaturze anglojęzycznej, poświęconej bibliografii tanecznej, Leslie Getz dokonała takiej klasyfikacji publikacji, która w przejrzysty sposób dzieli je na poszczególne działy. Taki podział pozwala na szybkie dotarcie do interesującej nas pozycji. Ponieważ w systemie UKD nie wyodrębniono Tańca, jako odrębnej klasy, należałoby się zastanowić, przy opracowywaniu bibliografii z tej dziedziny, nad dostosowaniem na grunt polski sprawdzonej klasyfikacji literatury tanecznej według L. Getz. Ważne jest bowiem to, co pisze A. Mendykowa o bibliografii: „Warunkiem szybkiego odnalezienia potrzebnej użytkownikowi informacji w ramach określonego spisu jest czytelność tekstu bibliograficznego, na którą składa się przejrzysta kompozycja całości, odpowiedni dla danej bibliografii, przemyślany układ zrębu głównego oraz właściwie dobrane indeksy i inne spisy pomocnicze. Przed przystąpieniem do poszukiwań użytkownik musi zorientować się według jakich zasad zostały uszeregowane tytuły, jak zbudowany jest opis i jakie zawiera elementy, a następnie jakimi bibliografia dysponuje indeksami"15.

W książce Dancers and Choreographers. A Selected Bibliography (Tancerze i choreografowie. Wybór bibliografii) w rozdziale Selected Reference Works (Wybór prac polecanych) L. Getz dokonuje następującego podziału literatury tanecznej ${ }^{16}$ :

- Dictionaries (Słowniki/opracowania ogólne) - słowniki i encyklopedie tańca

- Indexes (Indeksy) - m.in. przewodniki zawartości czasopism tanecznych

- Bibliographies (Bibliografie) - wszelkiego rodzaju bibliografie i katalogi poświęcone poszczególnym zagadnieniom tańca, w tym również osobom

15 Tamże, s. 32-33.

16 Wymieniam jedynie działy, które odpowiadają lub mogą w przyszłości odpowiadać istniejącej w Polsce literaturze tanecznej. L. Getz, Selected Reference Works [w:] tejże, Dancers and choreographers. A Selected Bibliography, Rhode Island \& London, 1995, s. 251-281. 
- Resources for Dance Research (Źródła badań nad tańcem) - publikacje dotyczące badań nad tańcem, $\mathrm{w}$ tym również historii tańca

- Ballet Guides (Przewodniki tańca) - przewodniki baletowe i modern dance (w tym również z podziałem chronologicznym i terytorialnym)

- Readings in Dance History, Theory \& Criticism (Historia, teoria i krytyka tańca - materiały) - pozycje z zakresu historii, teorii i krytyki tańca

- General, Period, Country \& Company Histories (Historia tańca i baletu) - historia ogólna (powszechna) tańca, okresy historyczne, historie tańca poszczególnych krajów i zespołów

- The Art of Choreography (Sztuka choreografii) - publikacje o sztuce choreograficznej (w tym również z podziałem na okresy historyczne, osoby i ich sposoby pracy)

- The Art of the Dancer (Problematyka zawodu tancerza)-życie tancerzy, problematyka związana z uprawianiem tego zawodu.

W drugiej swojej publikacji zatytułowanej Attitudes \& Arabesques ${ }^{17}$, w załączniku Organizing a Dance Library (Struktura biblioteki tanecznej) zamieszczonym na końcu publikacji, autorka literaturę systematyzuje według następujących działów ${ }^{18}$ :

- Reference Works (Prace polecane) - encyklopedie, słowniki, bibliografie, indeksy, przewodniki, antologie historii, teorii i krytyki tańca

- Frequently Consulted Works (Publikacje okolicznościowe, programy, foldery)-katalogi wystaw, konferencji, katalogi video, filmów i programów telewizyjnych poświęconych tańcowi

- Histories (Historia tańca i baletu) - książki z historii powszechnej tańca, poszczególnych okresów historycznych, krajów, zespołów

- Dancers \& Choreographers (Tancerze i choreografowie) - biografie i autobiografie, książki o dniu dzisiejszym tancerzy, wywiady, poświęcone pracy tancerza i sztuce choreograficznej

- Training, Education \& Recording Dance (Pedagogika i notacja tańca) - książki z zakresu edukacji tanecznej, technik tanecznych, nauczania tańca dzieci, notacji tańca, historii szkół tańca, instytucji, pracy nad ciałem, nauczyciele tańca

- Art and Dance (Sztuka i taniec) - taniec w sztuce, dekoracja i kostiumy, książki poświęcone poszczególnym projektantom, Edgar Degas, katalogi z wystaw projektów dekoracji i kostiumów, litografia, ikonografia

- Music and Dance (Muzyka i taniec) - ksiażki i przewodniki po muzyce tanecznej i baletowej, kompozytorzy muzyki tanecznej

- Literature/Fiction and Dance (Beletrystyka) - powieści i poezja o tematyce tanecznej, taniec i literatura

- Categories of Dance (Kategorie i style tańca, antropologia tańca) - publikacje dotyczace poszczególnych styli i kategorii tańca (np. taniec etniczny, ludowy, historyczny, towarzyski, jazz itd.), antropologia tanica

- Dance Photography (Fotografia taneczna) - albumy fotograficzne poszczególnych artystów, zespołów bądź poszczególnych fotografów

${ }^{17}$ Attitudes i arabesques (fran., l. mn.) - pozy tańca klasycznego.

18 Podobnie, jak w przypadku pierwszej klasyfikacii, podaję tylko te działy, które odnoszą się do tych zagadnień, z jakich w Polsce ukazały się publikacje. Getz L., Organizing a Dance Library, [w:] tejże Attitudes \& Arabesques, New York [2004], s. 1-5 (załącznika). 
- Health and Related Issues (Zdrowie i dziedziny pokrewne) - zdrowie tancerzy, anatomia i kinetoterapia (kinezjoterapia), psychologia w tańcu, taniec terapeutyczny (terapia poprzez ruch, choreoterapia)

- Philosophical Perspectives (Filozofia i studia nad ciałem) - filozofia tańca, estetyka tańca, analiza tańca, kody ciała/ekspresja/komunikacja

- Single-Subject Categories (Pozostała literatura przedmiotu) - książki dla dzieci i wszystkie te publikacje, których nie da się sklasyfikować według powyższych działów.

Klasyfikacje, które podaję za L. Getz, odnoszą się do publikacji książkowych. Spisy bibliograficzne czasopism tanecznych są dokonywane oddzielnie za poszczególne lata w układzie alfabetycznym tytułów poszczególnych pism. W Polsce niestety, poza nielicznymi okresami, ciagle brakuje pisma o tańcu. Wiele artykułów o tańcu ukazuje się w czasopismach teatralnych, muzycznych i społeczno-kulturalnych. Wobec takiego rozproszenia informacji w bibliografii zagadnień sztuki tanecznej powinny znaleźć się również opisy bibliograficzne poszczególnych artykułów zamieszczone w odpowiednim dziale, zgodnie z zagadnieniem, jakiego dotycza. Bowiem celem bibliografii tanecznej jest nie tylko wskazanie publikacji książowych o tańcu, ale przede wszystkim tych materiałów, które rozproszone są po wielkiej ilości pism. Materiał zawarty w czasopismach posiada bardzo szeroki zasięg: od obszernych, problemowych artykułów, poprzez recenzje i omówienia, aż do krótkich wzmianek i notatek informacyjnych. Pominięcie jakiejkolwiek informacji, choćby najkrótszej, byłoby ze szkodą dla ujęcia całokształtu problematyki tanecznej. Bibliografia nie mogłaby stanowić wówczas informatora-przewodnika o wyczerpującej treści, przydatnej tak w teoretycznej, jak i praktycznej pracy nad tańcem. Uważam, iż system klasyfikacji literatury tanecznej podany przez L. Getz można dostosować do istniejącego stanu publikacji tanecznych w naszym kraju. Opracowanie bibliografii tanecznej (z uwzględnieniem wydawnictw zwartych i artykułów) według jasno ustalonych działów pozwoliłoby w końcu na ocenę rzeczywistego stanu literatury tanecznej w Polsce, również pod względem merytorycznym.

W oparciu o systematyzację literatury tanecznej według L. Getz, proponuję dokonać klasyfikacji istniejących materiałów w tym zakresie według następujących działów ${ }^{19}$ :

1-Opracowania/zagadnienia ogólne - słowniki, almanachy, bibliografie, przewodniki 2 - Materiały źródłowe do badań nad tańcem

3 - Historia tańca i baletu - książki z historii powszechnej tańca, poszczególnych okresów historycznych, krajów, zespołów (w tym recenzje)

\section{4 - Teoria i krytyka tańca}

5 - Ludzie tańca: tancerze i choreografowie - biografie i autobiografie, książki o dniu dzisiejszym tancerzy, wywiady, publikacje poświęcone pracy choreograficznej

6 - Pedagogika tańca i baletu - książki z zakresu edukacji tanecznej, technik tanecznych, nauczania tańca dzieci, historii szkół tańca, instytucji, pracy nad ciałem, nauczyciele tańca

7 - Kategorie i style taneczne - publikacje dotyczące poszczególnych stylów i kategorii tańca (np. taniec etniczny, ludowy, historyczny, towarzyski, jazz itd.)

8 - Choreologia: antropologia tańca, kinetografia

9-Zdrowie i dziedziny pokrewne - zdrowie tancerzy, anatomia i kinetoterapia (kinezjoterapia), psychologia w tańcu, taniec terapeutyczny (terapia poprzez ruch, choreoterapia)

19 Zaproponowana przeze mnie koncepcja opracowania bibliografii tanecznej w Polsce wymaga jeszcze dopracowania. W ramach działów ogólnych, w zależności od ilości istniejących materiałów, można dokonać podziału na poddziały szczegółowe. Uważam jednak, iż przedstawione działy, odpowiadające poszczególnym zagadnieniom dotyczącym tej dziedziny, mogą być pomocne przy wstępnej klasyfikacji literatury w tym zakresie. 
10 - Filozofia i estetyka tańca

11 - Performatyka i dziedziny pokrewne

12 - Czasopisma

13 - Fotografia taneczna - albumy fotograficzne poszczególnych artystów, zespołów bądź poszczególnych fotografów

14 - Sztuka i taniec - taniec w sztuce, dekoracja i kostiumy, książki poświęcone poszczególnym projektantom, Edgar Degas, katalogi z wystaw projektów dekoracji i kostiumów, litografia, ikonografia

15 - Muzyka i taniec - książki i przewodniki po muzyce tanecznej i baletowej, kompozytorzy muzyki tanecznej

16 - Publikacje okolicznościowe, programy, foldery - katalogi wystaw, konferencji, programy spektakli i festiwali, katalogi video, filmów i programów telewizyjnych poświęconych tańcowi

17 - Proza i poezja

18 - Literatura dla dzieci

19 - (dział wolny).

Obecnie na stronach internetowych poświęconych sprawom tańca umieszczane są spisy książek o tematyce tanecznej, w wielu przypadkach na wyrost nazywane katalogami lub bibliografiami tańca ${ }^{20}$. W wielu przypadkach są to listy książek uszeregowane alfabetycznie według nazwisk autorów lub tytułów publikacji, bądź też autorzy tych zestawień dokonują podziału publikacji według ustalonych przez siebie działów. Żadna z tych systematyzacji nie zawiera całej literatury tanecznej wydanej w Polsce. Część podaje tytuły prac naukowych, wybranych artykułów z kilku tytułów czasopism. W oparciu o istniejące na portalach internetowych wykazy literatury tanecznej można próbować sporządzić przynamniej spis wydawnictw zwartych. Mimo to, takie podejście do kwestii bibliografii tanecznej nie rozwiązuje problemu. Coraz większe (i niestety w większości niezaspokojone) potrzeby środowiska tanecznego sprawiaja, iż bez rzetelnego opracowania bibliografii zagadnień sztuki tanecznej rozwój tańca i badań nad tańcem może zostać zahamowany.

\section{Co dalej?}

To pytanie bardzo często pojawia się w wypowiedziach osób związanych ze środowiskiem tanecznym w Polsce. Próbowano znaleźć na nie odpowiedź m.in. podczas I Kongresu Tańca, który odbył się w Warszawie w dn. 27-29 kwietnia 2011 r. pod hasłem Taniec ma głos zorganizowanym przez Instytut Muzyki i Tańca (IMIT). Badacz, recenzent czy edukator? Przestrzenie dialogu krytycznego to panel, podczas którego przedstawiono obecnie istniejące formy kształcenia profesjonalnego teoretyków tańca, tworzenia i badania teorii oraz zadania krytyki. Próbowano odpowiedzieć na pytanie, $\mathrm{w}$ jaki sposób istotne braki w publicznym systemie kształcenia praktyków i teoretyków tańca na poziomie akademickim warunkują rozwój tej sztuki, jej miejsce w debacie publicznej i odbiór. Odniesiono się również do istniejących narzędzi opisu i analizy tańca oraz podjęto próbę stworzenia nowego języka dyskusji o tej, stosunkowo nowej na gruncie polskim, formie aktywności kulturalnej. Część panelu poświęcona została zagadnieniu krytyki tańca, jej

${ }^{20}$ Zob. http://www.balet.pl/forum_balet/viewtopic.php?t=674\&highlight=ksi\%B1\%Bfki++ta\%F1cu, $\quad 08.10 .2011$, http://www.moderndance.pl/index.php? option=com_content\&task=category\&sectionid=8\&id=19\&Itemid=35, 30.10.2011, http://bibliografia.nowytaniec.pl/, 22.04.2011, http://www.nowytaniec.pl/?page_id=190, 22.04.2011, http://www.teatrtancadf.pl/pliki/obrazy/bibliografietaneczne.pdf, 08.10.2011. 
znaczeniu i roli. Uczestnicy Kongresu jednoznacznie stwierdzili, iż konieczna jest radykalna zmiana w traktowaniu sztuki tańca przez władze, aby mogła się ona w Polsce rozwijać. Bez znaczącego wzrostu nakładów na sztukę tańca i edukację (proporcjonalnie znacznie większego niż na inne dziedziny sztuki) w celu nadrobienia wieloletnich zaniedbań $w$ tej dziedzinie, nie będzie to możliwe. Wśród wielu działań służących poprawie sytuacji tańca i edukacji tanecznej uczestnicy Kongresu zaproponowali m.in.: reformę systemy szkolnictwa zawodowego w zakresie tańca dotyczącą wszystkich poziomów i ogólnego modelu edukacji, stworzenie programu edukacyjnego o tańcu oraz wprowadzenie go do powszechnego systemu edukacji, podjęcie działań służących rozwojowi wiedzy o tańcu i aktywności krytyczno-recenzenckiej wokół sztuki tańca oraz stworzenie strategii promocji sztuki tańca w Polsce i zagranicą. Powołanie przez Ministerstwo Kultury i Dziedzictwa Narodowego Polskiego Baletu Narodowego, Wydziału Teatru Tańca krakowskiej PWST w Bytomiu oraz Instytutu Muzyki i Tańca (organizatora Kongresu) środowisko taneczne traktuje, jako początek postulowanych zmian służących faktycznemu uznaniu autonomii sztuki tańca w Polsce ${ }^{21}$. Powołany 1 października 2010 r. IMIT w dziedzinie tańca, poza zorganizowaniem Kongresu, wspiera projekty edukacyjne, wydawnicze i archiwizacji zbiorów, promuje taniec polski na arenie międzynarodowej, stworzył wortal taniecpolska.pl, czyli na bieżąco aktualizowaną bazę polskiego tańca w wersji dwujęzycznej: polskiej i angielskiej. W planach departamentu tańca jest wydanie zbioru pokongresowego oraz książki o rozwoju tańca współczesnego w Europie Środkowej i Wschodniej ${ }^{22}$.

\section{Ośrodki badań Nad tańcem w Polsce}

Jak zatem wygląda sytuacja badań nad tańcem w Polsce? Jako jedna z pierwszych zapoczątkowała systematyczne badania nad tańcem Katedra Etnologii Uniwersytetu Warszawskiego (ok. 1935 r.), w których zastosowano notację Labanowską. Wybrane rezultaty tych badań zostały zaprezentowane w Archives Internationales de la Danse, jako część składowa Wystawy Światowej w Paryżu w 1937 r. ${ }^{23}$. Po wojnie, w roku 1954 reaktywowano kinetografię w ośrodku toruńskim z myślą o wprowadzeniu jej do badań nad folklorem tanecznym. Dzięki wprowadzeniu kinetografii do badań nad tańcem w roku 1957 (Muzeum Etnograficzne, Dział Tańca) oraz podjętej tam akcji ujednolicenia metody badawczej w skali krajowej otrzymaliśmy w Polsce pierwsze zbiory tańców ludowych nowocześnie udokumentowanych i zaopatrzonych w kinetogramy. Dzięki temu mamy do dyspozycji świetne prace z dziedziny folklorystyki tanecznej, historii form tanecznych, choreologii, zawierające obiektywny opis tańca wraz z notacjami materiału choreotechnicznego. Dzieła sztuki tanecznej muszą być bowiem utrwalone w piśmie, jeżeli mają być ocalone od zapomnienia. Obecnie od 1988 r. ponownie wykłada się kinetografię w Instytucie Choreologii w Poznaniu. Instytut prowadzi studium analizy i notacji ruchu (kinetografia Rudolfa von Labana) oraz warsztaty choreologiczne. Program zajęć obejmuje: analizę ruchu, ćwiczenia z zakresu eksploracji przestrzeni, notację ruchu - kinetografię, rekonstrucję tańców. Natomiast Zakład Ćwiczeń Muzyczno-Ruchowych Akademii Wychowania Fizycznego w Poznaniu skoncentrował działalność naukową dotyczącą badań nad tańcem m.in. na następujących zagadnieniach: społeczna rola tańca ludowego i działalność ludowych zespołów pieśni i tańca oraz

${ }_{21}$ Zob. http://www.kongrestanca.pl/pl/start-aktualnosci/postulaty-i-kongresu-tanca, 15.10.2011.

22 Zob.http://www.imit.org.pl

23 Por. P. Chynowski, Dance Research and Publication, [w:] S. J. Cohen (ed.), International Encylopedia of Dance, New York 2004, vol. 5, s. 220 oraz R. Lange, Kinetografia Labana, [w:] tenże, Podręcznik kinetografii, Poznań 1995, s. 17-21 oraz tenże, Ośrodki kinetografii, jej zastosowanie w świecie i w Polsce, [w:] tenże Podręcznik kinetografii, Poznań 1995, s. 21-22. 
walory tańca towarzyskiego. Pracownicy Zakładu prowadzą również studia dotyczące badań cech morfologicznych i motorycznych oraz zmian zachodzących pod wpływem ćwiczeń rytmicznych, tanecznych i gimnastyki artystycznej, rozwoju form gimnastyczno-tanecznych, tańca w zabawie i terapii człowieka oraz choreoterapii. Poznań to nie jedyne miejsce w Polsce, gdzie prowadzone są studia nad tańcem.

Kolejną placówką dydaktyczną i naukowo-badawcza, obejmującą opieką merytoryczną m.in. Sekcję Rytmiki i Pedagogiki Baletu, jest Katedra Edukacji Muzycznej Uniwersytetu Muzycznego im. F. Chopina w Warszawie. Działalność naukowa Katedry skupia się m.in. na psychologicznych i pedagogicznych problemach profesji artysty baletu. Są to unikatowe w skali kraju badania związane z funkcjonowaniem uczniów szkoły baletowej w Polsce, a także dorosłych tancerzy w zespołach baletowych.

Powstałe w styczniu 2009 r. Polskie Forum Choreologiczne jest stowarzyszeniem skupiającym osoby zajmujące się szeroko rozumianymi badaniami nad tańcem. Członkowie PFCH wywodzą się z różnych środowisk rozsianych na terenie całego kraju. Skupia ich jednak chęć doskonalenia własnego warsztatu pracy, wymiany doświadczeń, upowszechniania wiedzy o tańcu w naszym kraju oraz rozwijania polskiej choreologii. Swoje cele realizuje głównie przez konferencje i wydawnictwa (m.in. „Studia Choreologica”).

Z krótkiej prezentacji ośrodków studiów nad tańcem w Polsce jasno wynika, iż brakuje nam instytucji koordynującej. Wyniki badań w wielu przypadkach czekają zbyt długo na opublikowanie. Niestety prawdą jest, iż prace badawcze w tym zakresie $\mathrm{w}$ wielu jego aspektach są znacznie zapóźnione, w porównaniu do innych dziedzin humanistyki. Trudno uchwytne tworzywo tańca oraz uprzedzenia oparte na podstawach społecznych i moralnych znacznie utrudniają badania naukowe, a nawet je w zupełności uniemożliwiają. matyką badawcza, brak redaktorów o podstawowym przygotowaniu fachowym z dziedziny tańca.

\section{ZAKOŃCZENIE}

Co zatem zrobić, by poprawić obecny stan wydawnictw tanecznych i badań nad tańcem? Pisała już o tym wielokrotnie m.in. J. Pudełek. Jej postulaty nie straciły nic ze swej aktualności, ponieważ sytuacja nie uległa radykalnej zmianie. Autorka proponuje: „Opracować długofalowy, ramowy plan wydawniczy, oparty na dokładnej analizie potrzeb rynku i możliwościach wydawniczo-autorskich. Powierzyć realizację tego planu jednemu wydawnictwu, które powinno w tym celu zorganizować specjalną (...) redakcję, obsadzoną personelem przygotowanym fachowo za-

${ }^{24}$ Przez wieki taniec nie był uważany za przedmiot godny refleksji naukowej. Główną przyczyną jest fakt, iż taniec to zjawisko trudno uchwytne, obecne tylko wtedy, gdy człowiek jest pograżony w akcji tańczenia. Taniec nigdy nie staje się obiektem materialnym, przez co niełatwo poddaje się badaniom naukowym. Metodologia badań nad tańcem wypracowywała się z wielkim trudem. Badania utrudniał brak odpowiednich metod, narzędzi oraz systemu analizy i notacji ruchu. Studia nad tańcem rozpoczęto dopiero w $1930 \mathrm{r}$. wraz z powstaniem nowej dziedziny naukowej, zwanej przez Victora Junka - choreologią. Stworzona przez Rudolfa von Labana kinetografia umożliwiła po raz pierwszy w historii utrwalenie pelnego przebiegu ruchu. Daleko w tyle za innymi dziedzinami humanistyki, choreologia dopiero obecnie zdobywa sobie miejsce wśród innych dyscyplin naukowych, jako pełnowartościowa gałąź wiedzy. Mimo wysiłków wielu osób, na rzecz przywrócenia należytego miejsca sztuce tańca, jej status jest nadal dużo niższy aniżeli innych dziedzin sztuki. „Trudno jest bowiem przezwyciężyć uprzedzenia społeczne nagromadzone przez wieki. Stereotypowe wyobrażenia o zmysłowości, nieprzyzwoitości i frywolności tańca stale mu towarzyszą. Brak poważnego podejścia naukowego do tańca przyczynił się do traktowania go w najlepszym wypadku jako dopełnienia wykonawstwa muzycznego, czyli działalności o mniejszym znaczeniu w obrębie sztuki. Nawet gdy publicznie uznaje się istotność tańca, to podświadomie ujawniają się dawne uprzedzenia". R. Lange, Znaczenie tańca we wspótczesnej kulturze europejskiej: przeglad ogólny, [w:] D. Kubinowski (red.), Taniec -Choreologia - Humanistyka, Poznań 2000, s. 103. 
równo od strony redakcyjnej, jak i merytorycznej. Zobowiązać wszystkie inne wydawnictwa, które pragnęłyby sporadycznie włączyć się w akcję, do ścisłego konsultowania się z wydawnictwem "macierzystym «"25. Zdaniem J. Pudełek należy zapewnić pomoc w pracy już działającym autorom oraz ułatwić start osobom rozpoczynającym pisanie o tańcu. Można tego dokonać poprzez zorganizowanie ośrodka szeroko pojętej informacji naukowej, który w przyszłości należałoby przekształcić w placówkę badawczą. Ponadto istotne jest stworzenie samodzielnego czasopisma tanecznego, w którym publikowaliby najlepsi nasi fachowcy, a początkujący autorzy znaleźliby pole do próbowania własnych sił. Uważam, iż dobrym miejscem na powstanie takiego ośrodka byłby IS PAN. Jedynie taniec nie ma tam swojego zakładu. Początkowo mogłaby być to Sekcja Tańca przy Zakładzie Historii Teatru, przy wsparciu IMIT. Z czasem przekształciłaby się w samodzielną jednostkę badawczą Instytutu. Ważne jest, by osoby zatrudnione w tej Sekcji pochodziły z różnych ośrodków akademickich i reprezentowały szeroki wachlarz zainteresowań badań nad tańcem, szczególnie tańcem współczesnym. Myślę, iż nadszedł czas na radykalne zmiany służące uznaniu w Polsce tańca, jako samodzielnej dziedziny sztuki i nauki.

\section{BibLIOGRAFIA}

Cohen S. J. (ed.), International Encylopedia of Dance, vol. 5, New York 2004.

Chynowski P., Dance Research and Publication, [w:] Cohen S. J. (ed.), International Encylopedia of Dance, vol. 5, New York 2004.

Getz L., Attitudes \& Arabesques, New York [2004].

Getz L., Organizing a Dance Library, [w:] tejże, Attitudes \& Arabesques, New York [2004].

Getz L., Dancers and choreographers. A Selected Bibliography, Rhode Island \& London, 1995.

Getz L., Selected Reference Works, [w:] tejże, Dancers and choreographers. A Selected Bibliography, Rhode Island \& London, 1995.

Grabowska J., Szymajda J., Diagnoza stanu obecnego - Informacja, [w:] Grabowska J., Szymajda J., Raport o tańcu wspótczesnym w Polsce w latach 1989-2009, Kraków-Łódź 2009.

Grabowska J., Szymajda J., Raport o tańcu wspótczesnym w Polsce w latach 1989-2009, Kraków-Łódź 2009.

Gry medialne - analiza rozwoju cyfrowego rynku informacji o tańcu współczesnym, 2011, oprac. Sandra Wilk, Warszawa 2011.

Kozak E., Szymajda J., Machnicka B. (red.), Exchange/Change. Materiały z Międzynarodowej Konferencji w ramach VII Festiwalu Ciało/Umysł, Warszawa 2009.

Kubinowski D. (red.), Taniec-Choreologia - Humanistyka, Poznań 2000.

Królica A., Taniec w sieci i na rynku wydawniczym, [w:] Kozak E., Szymajda J., Machnicka B. (red.), Exchange/Change. Materiały z Międzynarodowej Konferencji w ramach VII Festiwalu Ciało/Umysł, Warszawa 2009.

Lange R., Bibliografia zagadnień sztuki tanecznej z lat 1963-1964, Warszawa 1969.

Lange R., Kinetografia Labana, [w:] tenże, Podręcznik kinetografii, Poznań 1995.

Lange R., Ośrodki kinetografii, jej zastosowanie w świecie i w Polsce, [w:] tenże, Podręcznik kinetografii, Poznań 1995.

Lange R., Podręcznik kinetografii, Poznań 1995.

Lange R., Znaczenie tańca we wspótczesnej kulturze europejskiej: przegląd ogólny, [w:] D. Kubinowski (red.), Taniec-Choreologia-Humanistyka, Poznań 2000.

Mendykowa A., Podstawy bibliografii, Warszawa 1986.

Ostrowska I., Bibliografia zagadnień sztuki tanecznej z lat 1945-1955, Warszawa 1959.

Ostrowska I., Bibliografia zagadnień sztuki tanecznej z lat 1956-1957, Warszawa 1960.

Ostrowska I., Bibliografia zagadnień sztuki tanecznej z lat 1958-1960, Warszawa 1962.

Ostrowska I., Bibliografia zagadnień sztuki tanecznej z lat 1961-1962, Warszawa 1964.

Ostrowska I., Bibliografia zagadnień sztuki tanecznej z lat 1965-1966, Warszawa 1968.

Pudełek J., Powojenne ksiażki o balecie, „Ruch Muzyczny” 1973, nr 14.

\section{Netografia}

http://www.balet.pl/forum_balet/index.php.

http://www.balet.pl/forum_balet/viewtopic.php?t=674\&highlight=ksi\%B1\%Bfki++ta\%F1cu, 08.10.2011.

25 J. Pudełek, Powojenne ksiązki o balecie, „Ruch Muzyczny” 1973, nr 14, s. 16. 
http://bibliografia.nowytaniec.pl/, 22.04.2011.

http://www.bn.org.pl.

http://www.ispan.pl/pl/biblioteka.

http://www.imit.org.pl.

http://www.kongrestanca.pl/pl/start-aktualnosci/postulaty-i-kongresu-tanca, 15.10.2011.

http://www.moderndance.pl/index.php?option=com_content\&task=category\&sectionid=8\&id=19\&Itemid=35, 30.10.2011

http://www.nowytaniec.pl/?page_id=190, 22.04.2011

http://www.teatrtancadf.pl/pliki/obrazy/bibliografietaneczne.pdf, 08.10.2011

\section{STRESZCZENIE}

Niniejszy artykuł przedstawia stan literatury tanecznej w Polsce oraz jest próbą opracowania polskiej bibliografii tanecznej. Na wstępie autorka omawia istniejący stan literatury tanecznej w naszym kraju. Następnie prezentuje klasyfikację publikacji tanecznych według Leslie Getz. W oparciu o przedstawioną systematykę, autorka podejmuje próbę opracowania struktury systemu porządkującego ogół zagadnień z tej dziedziny sztuki i nauki. Zaproponowany układ spisu bibliografii tanecznej w Polsce pozwoliłby na ujęcie całokształtu problematyki w tym zakresie. W zakończeniu autorka omawia działalność naukową poszczególnych ośrodków badawczych oraz przedstawia postulaty dotyczące poprawy sytuacji badań nad tańcem w Polsce.

Słowa kluczowe: literatura taneczna - Polska, czasopisma taneczne, książki taneczne, taneczne strony internetowe, polska bibliografia tańca, badania nad tańcem w Polsce, organizowanie biblioteki tanecznej.

\section{Bibliography of Dance. Dance Studies in Poland: Research Perspectives}

\section{Summary}

The objective of this paper is twofold: (1) to review the literature on dance in Poland and (2) to make Polish dance bibliography more elaborate.

First, the essay discusses the current state of research on dance in Poland. Second, it presents the classification of dance publications by Leslie Getz and attempts to create a bibliography of the dance catalogue in Poland. Finally, it comments on the scientific activity of Polish research institutions studying dance and suggests some improvements to the current situation of dance research in Poland.

\section{Key words}

dance literature - Poland, dance periodicals, dance books, dance web sites, polish dance bibliography, dance research in Poland, organizing a dance library. 
